\title{
INFORMATIZATION OF GLOBAL ECONOMIC DEVELOPMENT AND PLACE OF UKRAINE IN THE INFORMATION ENVIRONMENT
}

\author{
Nadezhda Kazakova \\ $\mathrm{PhD}$ (Geographic Sciences), Professor \\ V. N. Karazin Kharkiv National University \\ Svobody sq., 6, Kharkiv, Ukraine, 61022 \\ e-mail: meo_1@ukr.net \\ ORCID: https://orcid.org/0000-0002-2455-7503 \\ Inna Davydenko \\ PhD (Philology) \\ V. N. Karazin Kharkiv National University \\ Svobody sq., 6, Kharkiv, Ukraine, 61022 \\ e-mail: i.v.davydenko@karazin.ua \\ ORCID: https://orcid.org/0000-0001-6379-343X \\ Alla Shtykolenko \\ Student \\ V. N. Karazin Kharkiv National University \\ Svobody sq., 6, Kharkiv, Ukraine, 61022 \\ e-mail: allaalla9955@gmail.com \\ ORCID: https://orcid.org/0000-0003-1628-6421
}

\begin{abstract}
This publication studies the impact of information and communication technologies on the global economy; using the main Indices (Network Readiness Index, Global Innovation Index, E-Government Development Index, EParticipation Index and ICT Development Index) the authors analyzed at a on information society development. Information and communication technologies are an integral part of the global economy; the decisive factor of the country's economic development is the level of ICT use in various areas of public life. The fact of the transition from the "old industrial order" to the "new economy", which affects the processes of production, processing and transmission of information, transforming the economy, politics and culture in the modern world, becomes obvious. The rapid development and spread of new ICT technologies acquire the nature of the global information revolution. This leads to an irreversible transformation into a new post-industrial type of society. The main idea of this research is relevant within the scientific and practical terms.

The subject of the research is the informatization of global economic development. The purpose of the research is to study informatization processes and to analyze ICT as a resource of the modern development of the world economy. The object of the study is the dynamics of the informatization process development and the detailed analysis of the impact of ICT on the world economy. The scientific methods are a system analysis, a factor analysis and a graphical method. The study reveals new components of the world economy and countries' positions on the global market. The authors conclude that due to the development of ICT, almost all areas of the economy, which have an impact on the development of states and people's welfare, are getting intensified.

Key words: Economic development, economy, globalization, information and communication technologies,
\end{abstract} informational environment, informatization.

Problem formulation. The process of globalization, the strengthening of regional economic, political integration are considered to be a defining characteristic of the modern world economy [3]. The problem of globalization is defined as a process associated with the information revolution, as a result of which our world is actively turning into a global, unified, real-time system [7].

The economic integration should be seen as a process of economic interaction between countries that bring together national economies, where the basis is stable interconnections and the international division of labor [4]. The globalization of world economic relations, the absence of information boundaries between states, which means the development of an information society in the states, regardless of their classification (developed / developing) depend on the introduction of the latest advances in science and technology in the field of communications and information, which are now used 18 by the economic synergy and are an integral part of the modern life.

Under the conditions of globalization and widespread use of ICT, all the structures of the society are being transformed. The transition to the information society is fully consistent with the concepts of sustainable development: the economy is formed on the basis of knowledge and information, rather than on expanding the consumption of natural resources[2].

Analysis of recent studies and published works. The study of informatization of global economic development is becoming very relevant nowadays. V. Sidenko [7], A. Golikov [4], S. Dyatlova [2], M. Kizima, I. Matyushenko, I. Shostak [6], V. Sidorov, S. Glazyev, V. Baburin, Y. Yakovtsy and others have carried out the research on the formation society and globalization. However, despite the number of modern scientific works, the assessment of the state of the modern information environment and the impact 
of ICT on the world economy has not been sufficiently examined.

The basic ideas. Information and knowledge have always been the main components of economic growth, and technological development has determined the standard of living, the development of society and the social forms of economic organization. Flexible and powerful information technology made it possible to turn information into a product of the production process. The generation, processing and transmission of information are gradually becoming the main sources of labor productivity. Under the influence of informatization there are new methods of competition, there is a change in the structure of the economy [2].

Traditionally, there are only three sectors in the structure of the economy: 1) primary (extraction of raw materials and their processing); 2) secondary (enterprises of manufacturing industries); 3) tertiary (enterprises of the service sector). However, this classification is not sufficiently complete at the present stage, because it does not take into account the growing role of the information sector. In this regard, it is advisable to classify the structure of the economy in six sectors (Fig. 1.), paying particular attention to the ICT sector, which includes types of economic activities that are directly related to software (design, production and trade), communication equipment, computer technology, consumer electronics, as well as to system integration, to the provision of information technology and telecommunication services [1].

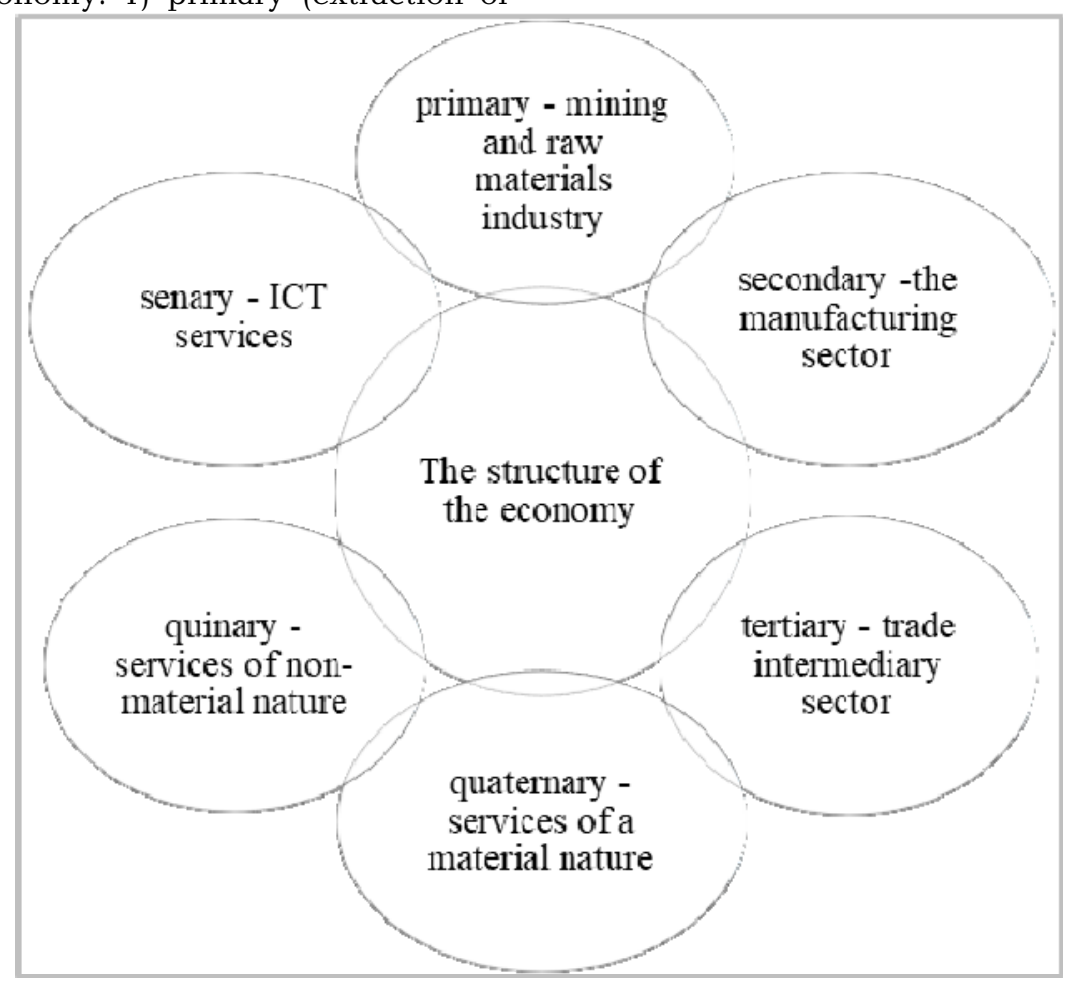

Fig. 1. The structure of the economy

Source: Created by the author according to data [2]

Nowadays, the selection of information and communication services as an independent sector of the economy is a prerequisite for assessing the potential of development and the degree of countries moving to the "new economy". In the Western countries, scientific-intensive industries are the basis of a rapidly developing of the information economy. Due to these industries, products with high intellectual capacity are manufactured. These are, first of all, the electronic industry, construction of robots, the production of electronic computers, etc. Nowadays, information economy is characterized by an increase in the service sector. The information sector of the economy is the basis for the gradual transformation of the countries into the system of post-industrial ones, and then - into the information ones.
Due to information and communication technologies, the business environment increases productivity, simplifies and significantly accelerates communications at the external and internal levels. This has become possible due to the increased mobility, the introduction of various systems, including electronic document management. Also, there are distant service markets, security and safety, public health services and education. New forms of interaction between business and customers arise due to the fast access to the Internet. This increases the efficiency, dynamics and importance of the business environment.

The largest hotel companies in the world are a demonstrative example of implementation of Internet technologies in business. Marriot International includes more than 6700 hotels in 130 countries, with 
a total capacity of 1190604 rooms [11]; Inter Continental Hotels Group (IHG) has 5348 hotels in 100 countries with a total of 798075 rooms $[9,10]$;
Wyndham Hotels \& Resorts includes 8422 hotels in 66 countries with a total capacity of 728195 rooms [8] (Table 1).

Table 1

Financial indicators of the largest hotel companies, 2016 - 2017 (bn US dollars)

\begin{tabular}{|c|c|c|c|c|}
\hline Company & Year & Net income & Total assets & Equity \\
\hline \multirow{2}{*}{ Marriot International } & 2017 & 1,372 & 23,95 & 3,731 \\
\cline { 2 - 5 } & 2016 & 0,780 & 24,14 & 5,357 \\
\hline \multirow{2}{*}{ Inter Continental Hotels Group } & 2017 & 0,593 & 3,175 & -858 \\
\cline { 2 - 5 } & 2016 & 0,417 & 2,927 & -767 \\
\hline \multirow{2}{*}{ Wyndham Hotel Group } & 2017 & 0,872 & 1,040 & 883 \\
\cline { 2 - 5 } & 2016 & 0,612 & 0,982 & 718 \\
\hline
\end{tabular}

Source: Created by the author according to data $[8,10,12,13]$

The creation of interactive web pages by companies has provided many amenities for potential customers seeking a hotel that meets all requirements, reservations with the ability to view the hotel with a "virtual (3D) tour".

Due to the ICT sector, e-commerce has emerged in the trading sector, which is now growing at a fast pace and the newest online trading platforms are being created for a convenient and fast interconnection between counterparties; the process of transaction trading is accelerating. ICTs also play an important role in the country's financialisation. Information and communication infrastructures provide instant money transfers between banks of the world, electronic payments, telecommunication payment systems
(SWIFT, TARGET, etc.), the proper functioning of various funds, banking institutions etc. In the modern world, under the conditions of fierce competition, the country which produces and sells high-tech products can attract more investment, because the final price of this type of product includes a very highlevel of added value. Today ICT forms the basis for the "information society".

The importance of the information economy is increasing day by day and there is no doubt that the key to success is the ability to find and use the necessary information efficiently, clearly and quickly. In the following graph, we consider the percentage of people using the Internet in 2017 by age (Fig. 2.).

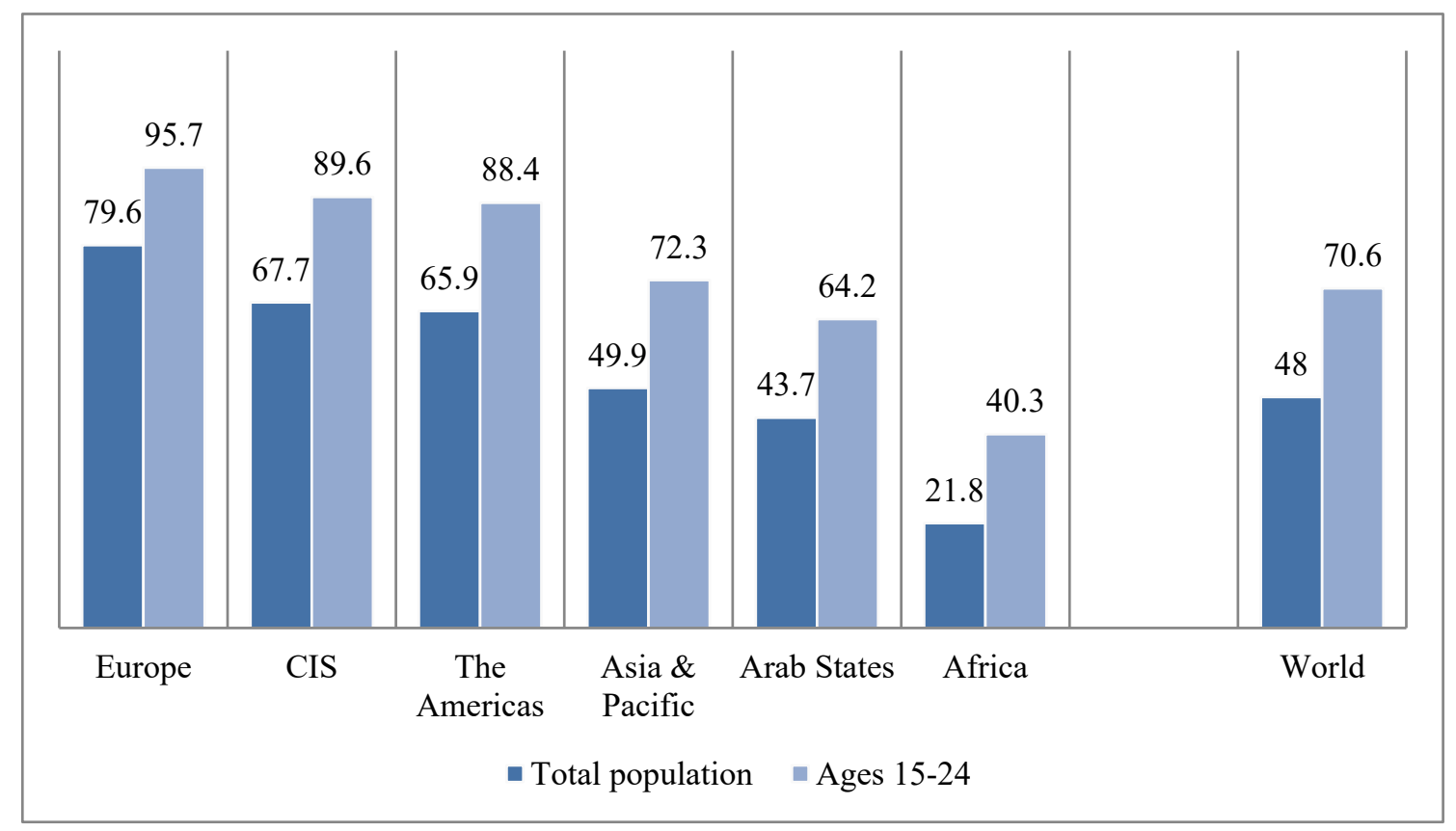

Fig. 2. Proportion of individuals using the Internet in 2017 / age Source: Created by the author according to data [14]

The proportions in this table indicate the number of people using the Internet, as to the percentage of 20 the global population, and the number of people aged from 15 to 24 years who use the Internet, as to the 
percentage of the total population aged from 15 to 24 years. The graph shows that the European region has the leading position in the number of Internet users, in which $79.6 \%$ of the population use the Internet. The group (15 - 24 years) equals to $70.6 \%$. Young people actively use the Internet in everyday life in all over the world, without exception. In Ukraine, the number of
Internet users increases every year. In large cities, the number of broadband connections increases [6]. The main leaders in this segment of the market are Volya, Triolan, Ukrtelecom. The index given in a graphic includes users who access the Internet from all possible devices (including mobile phones) over the past 12 months (Fig. 3.).

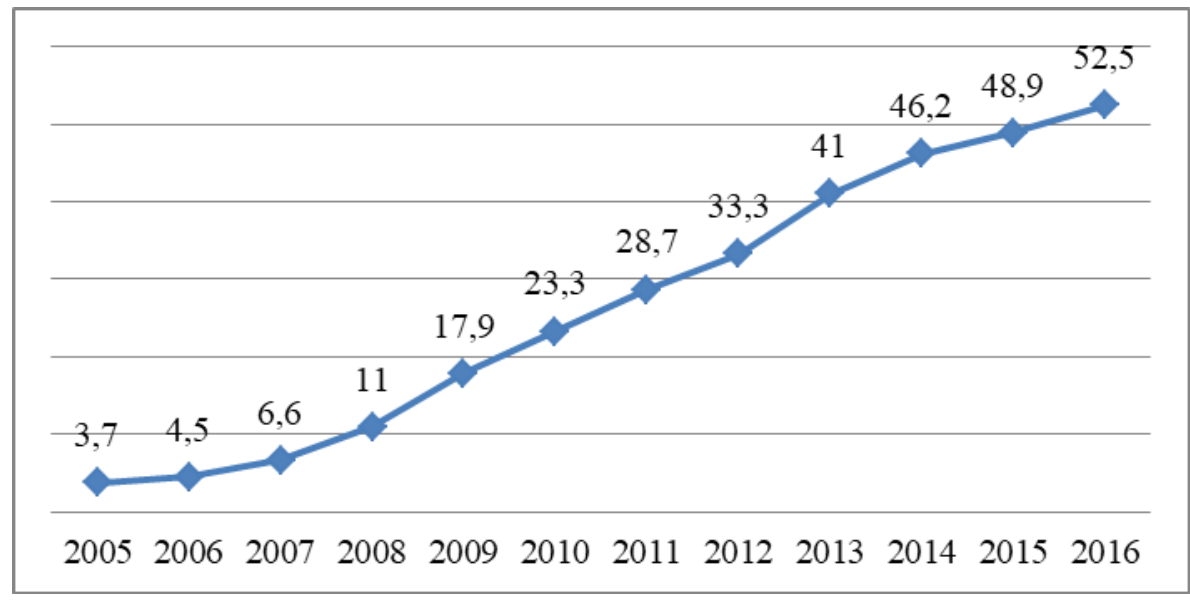

Fig. 3. Internet users in Ukraine (\% of population)

Source: Created by the author according to the data [5]

The position of countries in the global information technology market is determined by the rating research. The five main indexes reflect the most recent data on the state of the development of the information society, namely:

- $\quad$ NRI - Network Readiness Index

- GII - Global Innovation Index

- $\quad$ EGDI - E-Government Development Index

- $\quad$ EPART - E-Participation Index
- $\quad$ IDI - ICT Development Index.

Network Readiness Index is a complex indicator that characterizes the level of ICT development in the countries around the world. It is used as a method for an analysis for constructing comparative ratings, which clearly reflects the level of information society development in different countries of the world (Table 2).

Top 10 countries of the world and Ukraine's position according to the Network Readiness Index, $2015-2016$

\begin{tabular}{|l|c|c|c|}
\hline Country/Economy & Value & $\begin{array}{c}\text { 2016 Rank } \\
\text { (out of 139) }\end{array}$ & $\begin{array}{c}\text { 2015 Rank } \\
\text { (out of 143) }\end{array}$ \\
\hline Singapore & 6.0 & 1 & 1 \\
\hline Finland & 6.0 & 2 & 2 \\
\hline Sweden & 5.8 & 3 & 3 \\
\hline Norway & 5.8 & 4 & 7 \\
\hline United States & 5.8 & 5 & 4 \\
\hline Netherlands & 5.8 & 6 & 8 \\
\hline Switzerland & 5.8 & 7 & 9 \\
\hline United Kingdom & 5.7 & 8 & 10 \\
\hline Luxembourg & 5.7 & 9 & - \\
\hline Japan & 5.6 & 10 & 71 \\
\hline- & - & - & 64 \\
\hline Ukraine & 4.2 & & 7151 \\
\hline
\end{tabular}

Source: Created by the author according to the data [15]

The leaders of the rating are Singapore, Finland and Sweden. The Top 10 also included the following countries: Norway, the USA, the Netherlands, Switzerland, the United Kingdom, Luxembourg,
Japan. Ukraine has the 64th positions among 139 countries, rising by 7 points, comparing with 2015 . According to the Network Readiness Index in 2016 Haiti, Burundi and Chadare certain outsiders. 


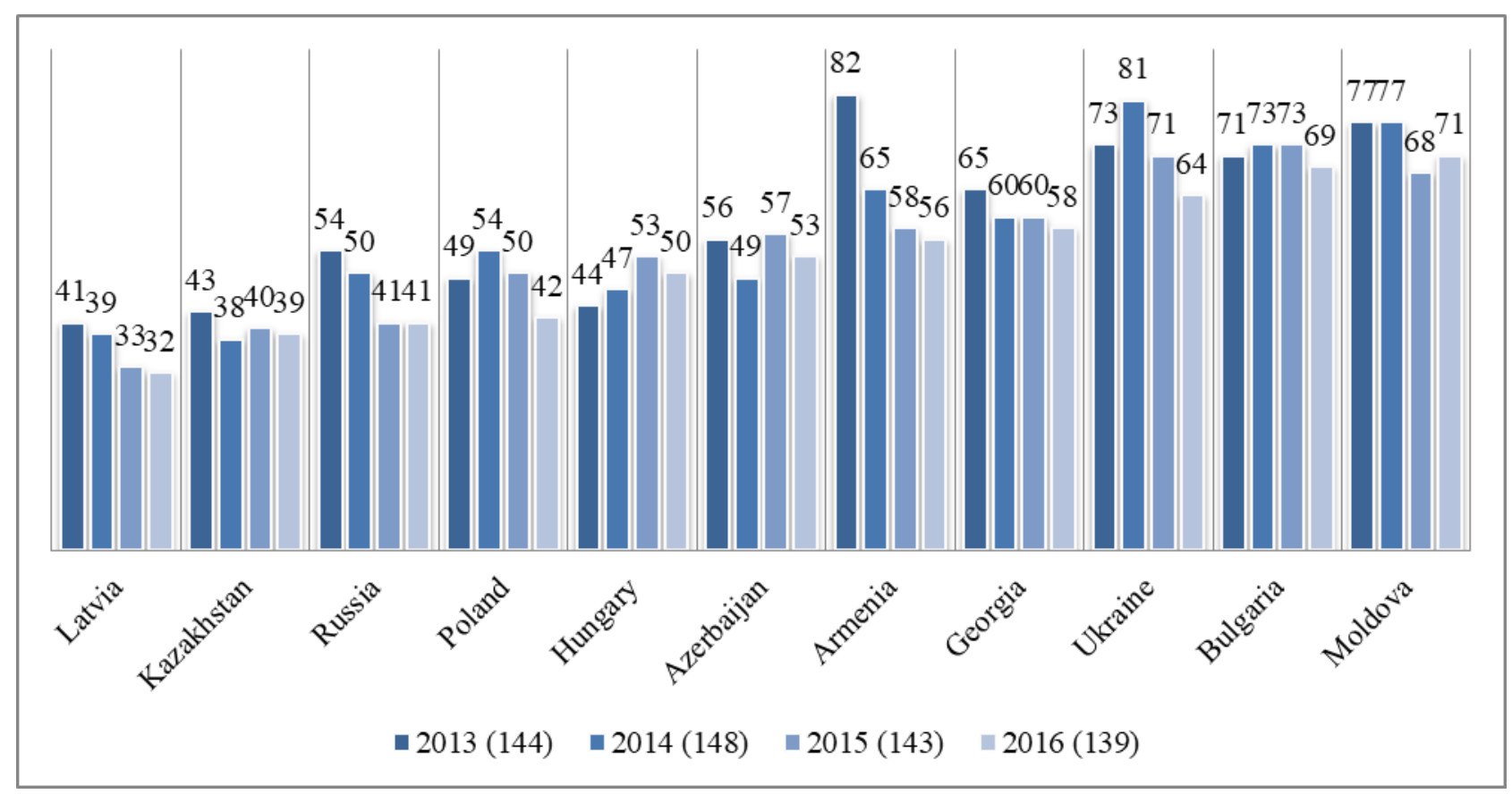

Fig. 4. Dynamics of changing value of the Network Readiness Index in Ukraine and other countries, $2013-2016$

Source: Created by the author according to the data [14]

Despite the fact that our indicators are improving, Ukraine continues to be very much inferior to the CIS countries and the countries of Eastern Europe (Fig. 4.). The reason lies in lagging behind the components that characterize the political and regulatory environment - 113th among 139 countries, a very low level of information use and communication technologies by the government114th. The advantages of Ukraine remain the availability of ICTs, which allows it to take 6 steps, but according to the assessment of the level of competition in the market of telecommunication services, we lose 3 points a year, which has moved us to 80 th position among 139 countries.
The Global Innovation Index is the world ranking by the indicator of the level of innovation development. The research evaluates activities, institutes, human capital, the level of market and business development and infrastructure. The index is calculated on the basis of more than 80 parameters, including the number of created mobile applications, scientific and technical publications, applications for intellectual property rights and the cost of education. The Cornell University is ranked annually by the INSEAD School of Business and the World Intellectual Property Organization (WIPO). The rating of countries according to the Global Innovation Index has been published annually since 2007 (Table 3).

Global Innovation Index 2018 rankings

Table 3

\begin{tabular}{|l|l|l|}
\hline \multicolumn{1}{|c|}{ Country/Economy } & Score $(0-100)$ & Rank \\
\hline Switzerland & 68.40 & 1 \\
\hline Netherlands & 63.32 & 2 \\
\hline Sweden & 63.08 & 3 \\
\hline United Kingdom & 60.13 & 4 \\
\hline Singapore & 59.83 & 5 \\
\hline United States of America & 59.81 & 6 \\
\hline Finland & 59.63 & 7 \\
\hline Denmark & 58.39 & 8 \\
\hline Germany & 58.03 & 9 \\
\hline Ireland & 57.19 & 10 \\
\hline- & - & - \\
\hline Ukraine & 38.52 & 43 \\
\hline
\end{tabular}

Source: Created by the author according to the data [11]

This rating is headed by Switzerland. Among the leading innovation countries, there are Netherlands, 22
Sweden, United Kingdom, Singapore, USA, Finland, Denmark, Germany, Israel. China entered the Top 20 
for the first time. Ukraine has become entrenched in the Top 50 and improved last year's result. The highest indicators of innovation are demonstrated by our country in education and science (43rd place) and business (46th place in the rating). At the same time, institutions (107th place) and infrastructure (89th place) remain the least innovative. Neighboring Hungary took 33rd place, Slovakia - 36th, Poland 39th, Russia - 46th, Moldova - 48th, Romania 49th, Belarus - 86th.

The E-Government Development Index is a comprehensive indicator, which assesses the capacity and willingness of government agencies to use ICTs to provide citizens with public services. The study contains a systematic assessment of trends in the use of information and communication technologies by government structures (Table 4).

The E-Participation Index is an indicator of the development of active communication services between the state and citizens of the country that includes: 1) the use of interactive services to facilitate the provision of information to citizens (e-information); 2) consultation and interaction with the citizens of the country (e-consultation); 3) participation of citizens in the processes of making state decisions (e-decision-making) (Table 5).

Table 4

EGDI - Top 10 Countries and Ukraine, 2018

\begin{tabular}{|l|c|c|c|}
\hline Country & Rank & $\begin{array}{c}\text { Changing } \\
\text { position } \\
2018 / 16\end{array}$ & Index \\
\hline Denmark & 1 & +8 & 0.9150 \\
\hline Australia & 2 & - & 0.9053 \\
\hline Republic of Korea & 3 & - & 0.9010 \\
\hline United Kingdom & 4 & -3 & 0.8999 \\
\hline Sweden & 5 & +1 & 0.8882 \\
\hline Finland & 6 & -1 & 0.8815 \\
\hline Singapore & 7 & -3 & 0.8812 \\
\hline New Zealand & 8 & - & 0.8806 \\
\hline France & 9 & +1 & 0.8790 \\
\hline Japan & 10 & +1 & 0.8783 \\
\hline- & - & - & - \\
\hline Ukraine & 82 & -20 & 0.6165 \\
\hline
\end{tabular}

Source: Created by the author according to the data [15]

EPART - Top 11 Countries and Ukraine, 2018

Table 5

\begin{tabular}{|l|c|c|}
\hline \multicolumn{1}{|c|}{ Country } & Rank & Index \\
\hline Republic of Korea & 1 & 1.0000 \\
\hline Denmark & 1 & 1.0000 \\
\hline Finland & 1 & 1.0000 \\
\hline Netherlands & 4 & 0.9888 \\
\hline Japan & 5 & 0.9831 \\
\hline New Zealand & 5 & 0.9831 \\
\hline Australia & 5 & 0.9831 \\
\hline Spain & 5 & 0.9831 \\
\hline United Kingdom & 5 & 0.9831 \\
\hline United States of America & 5 & 0.9831 \\
\hline Norway & 11 & 0.9775 \\
\hline Ukraine & - & - \\
\hline Und & 75 & 0.6854 \\
\hline
\end{tabular}

Source: Created by the author according to the data [15]

European countries are actively pursuing the development of e-government; North and South America and Asia have almost equal positions, speaking about the high and middle level of egovernment. African countries are also struggling to improve the level of e-government development.
Denmark has the largest index - 0.915 (in 2016, Denmark took the 9 th position in the rating). Australia and South Korea took their places - the 2nd and 3rd respectively. Britain, which in 2016 headed the rating, was placed 4th two years later. Ukraine was 82nd in the list. 
The E-Participation Index, which reflects the development of active communication services between citizens and the state, is headed by South Korea, Denmark and Finland, while Ukraine has fallen to the 75th place (in 2017 it was 32nd, in 2016 77 th place in the ranking) $[16,17]$.

The IDI indicator was created by analysts of the International Telecommunication Union in order to calculate the development of the ICT sector of the world, and hence the level of information of its population. The table below shows the leading countries in the world according to their regional IDI rating. For example, Denmark having the index of IDI 8.71 is the third in Europe, but the 4th in the world, after Sweden - 8.74 (Table 6).

Highest-ranking economies, IDI 2017

\begin{tabular}{|c|c|c|c|c|c|c|c|}
\hline \multicolumn{4}{|c|}{ Europe } & \multicolumn{4}{|c|}{ Arab States } \\
\hline $\begin{array}{l}\text { Regional } \\
\text { rank }\end{array}$ & $\begin{array}{c}\text { Global } \\
\text { rank }\end{array}$ & Economy & IDI & $\begin{array}{l}\text { Regional } \\
\text { rank }\end{array}$ & $\begin{array}{c}\text { Global } \\
\text { rank }\end{array}$ & Economy & IDI \\
\hline 1 & 1 & Iceland & 8,98 & 1 & 31 & Bahrain & 7.60 \\
\hline 2 & 3 & Switzerland & 8.74 & 2 & 39 & Qatar & 7.21 \\
\hline 3 & 4 & Denmark & 8.71 & 3 & 40 & UAE & 7.21 \\
\hline 4 & 5 & $\begin{array}{c}\text { United } \\
\text { Kingdom }\end{array}$ & 8.65 & 4 & 54 & Saudi Arabia & 6.67 \\
\hline 5 & 7 & Netherlands & 8.49 & 5 & 62 & Oman & 6.43 \\
\hline \multicolumn{4}{|c|}{ Asia and the Pacific } & \multicolumn{4}{|c|}{ CIS } \\
\hline $\begin{array}{l}\text { Regional } \\
\text { rank }\end{array}$ & $\begin{array}{c}\text { Global } \\
\text { rank }\end{array}$ & Economy & IDI & $\begin{array}{l}\text { Regional } \\
\text { rank }\end{array}$ & $\begin{array}{c}\text { Global } \\
\text { rank }\end{array}$ & Economy & IDI \\
\hline 1 & 2 & Korea (Rep.) & 8.85 & 1 & 32 & Belarus & 7.55 \\
\hline 2 & 6 & China & 8.61 & 2 & 45 & Russia & 7.07 \\
\hline 3 & 10 & Japan & 8.43 & 3 & 52 & Kazakhstan & 6.79 \\
\hline 4 & 13 & New Zealand & 8.33 & 4 & 59 & Moldova & 6.45 \\
\hline 5 & 14 & Australia & 8.24 & 5 & 65 & Azerbaijan & 6.20 \\
\hline \multicolumn{4}{|c|}{ The Americas } & \multicolumn{4}{|c|}{ Africa } \\
\hline $\begin{array}{l}\text { Regional } \\
\text { rank }\end{array}$ & $\begin{array}{c}\text { Global } \\
\text { rank }\end{array}$ & Economy & IDI & $\begin{array}{l}\text { Regional } \\
\text { rank }\end{array}$ & $\begin{array}{c}\text { Global } \\
\text { rank }\end{array}$ & Economy & IDI \\
\hline 1 & 16 & United States & 8.18 & 1 & 72 & Mauritius & 5.88 \\
\hline 2 & 29 & Canada & 7.77 & 2 & 90 & Seychelles & 5.03 \\
\hline 3 & 34 & Barbados & 7.31 & 3 & 92 & South Africa & 4.96 \\
\hline 4 & 37 & $\begin{array}{c}\text { St. Kitts } \\
\text { and Nevis }\end{array}$ & 7.24 & 4 & 93 & Cape Verde & 4.92 \\
\hline 5 & 42 & Uruguay & 7.16 & 5 & 105 & Botswana & 4.59 \\
\hline
\end{tabular}

Source: Created by the author according to the data [13]

IDI rating in 2017 is headed by Iceland. There are significant differences between the geographic regions in the levels of ICT development, according to the above table IDI. There is also a significant difference in the experience of individual countries in each region. These differences are mainly related to the levels of economic development.

The average IDI of 2017 in the region of Africa is 2.64. Mauritius is in the upper half of the global distribution of IDI.

In North and South America, the United States and Canada are the leaders. The most visible improvement in this region is noted in the countries of South and Central America and the Caribbean, which have an average rating.
The region of the Arab States is also extremely diverse in terms of IDI in 2017. This region is home to a number of high-income countries - Bahrain, Qatar and the UAE. Significant improvements can be noted in middle-income countries, where, compared to countries located in the upper and lower parts of the regional distribution, the average figures have more than doubled.

Seven countries in the Asia-Pacific region have IDI values above 7.50 points and therefore belong to the upper quartile, including the Republic of Korea, which is 2nd among all countries of the world.

In the CIS, only Belarus is in the upper quartile of the IDI, 2017. Ukraine was not among the Top 5 
countries, it took only 8th place, and 79th place all over the world -5.62 .

Europe is the region with the highest average rate among the regions of the world ( 7.50 points). Twenty eight countries are in the upper quartile out of the 40 countries of the region. The most significant improvements were shown by Cyprus and Turkey.

Despite the rapid spread of information and communication technologies, there are significant digital divides between countries and regions. However, it should also be noted that there is progress in the growth of ICT in the least developed countries (the ability to establish connections, use of the Internet, etc.). At the moment, more than half of households in the world have access to the Internet, although it turned out that the growth rate has fallen by5\% per year. The significant progress in overcoming the digital gender gap in different regions should also be noted.
Conclusion. Thus, the globalization of world economic relations, the rapid development of the information society in all countries of the world appear due to the rapid implementation of advances in the field of information and communications, which are now an integral part of everyday life. ICT technologies have become the main driver of the economic development of states in the modern world. Due to the development of ICT, almost all areas of the economy are getting intensified, which makes it possible to create and develop new industries in the economy, science and technology. The branched set of the index system allows us to consider and evaluate the potential of countries in the world market of information technologies, to determine the degree of their readiness for a network economy, to assess the state of our country's participation in the modern information environment.

\section{ІНФОРМАТИЗАЦІЯ ГЛОБАЛЬНОГО ЕКОНОМІЧНОГО РОЗВИТКУ ТА МІСЦЕ УКРАЇНИ В ІНФОРМАЦІЙНОМУ ПРОСТОРІ}

Казакова Надія Артурівна, канд. географ. наук, професор, Харківський національний університет імені В. Н. Каразіна, м. Свободи, 6, м. Харків, Україна, 61022, e-mail: meo_1@ukr.net, ORCID: https://orcid.org/0000-0002-2455-7503

Давиденко Інна Володимирівна, канд. фрілолог.. наук, Харківський національний університет імені В. Н. Каразіна, м. Свободи, 6, м. Харків, Україна, 61022, e-mail: i.v.davydenko@karazin.ua, ORCID: https://orcid.org/0000-0001-6379-343X

Штиколенко Алла Миколаївна, студент, Харківський національний університет імені В. Н. Каразіна, м. Свободи, 6, м. Харків, Україна, 61022, e-mail: allaalla9955@gmail.com, ORCID: https://orcid.org/0000-0003-1628-6421

У даній публікації досліджується вплив інформаційно-комунікаційних технологій на світову економіку; використовуючи основні Індекси (Індекс мережевої готовності, Глобальний індекс інновацій, Індекс розвитку електронного уряду, Індекс електронної участі та Індекс розвитку ІКТ) автори аналізують дані щодо розвитку інформаційного суспільства. Інформаційнокомунікаційні технології являють собою невід'ємну частину світової економіки, адже вирішальним фрактором економічного розвитку держави виступає ступінь використання ІКТ у різних областях суспільного життя. Очевидним стає фракт переходу від «старого індустріального порядку» до «нової економіки», яка зачіпає процеси виробництва, обробки і передачі інформації, трансформуючи економіку, політику і культуру в сучасному світі.

Стрімкий розвиток та розповсюдження нових ІКТ технологій набуває характеру глобальної інформаційної революції. Це веде до незворотної трансформації в новий постіндустріальний тип суспільства. Тема даного дослідження є актуальною в науковому та в практичному плані. Предметом дослідження в статті є інформатизація глобального економічного розвитку. Мета - вивчення інформатизаційних процесів та аналіз ІКТ як ресурсу сучасного розвитку світової економіки. Завдання: дослідження динаміки розвитку інформатизаційних процесів та детальний аналіз впливу ІКТ на глобальний економічний розвиток. Використовуються загальнонаукові методи: системний аналіз, ффакторний аналіз, граффічний метод. Результати даного дослідження: виявлено нові сектори структури економіки та проаналізовано позиціонування країн на світовому ринку. Автори роблять висновок, що завдяки розвитку ІКТ інтенсивно зростають практично всі сфери економіки, які впливають на розвиток держав і добробут людей.

Ключові слова: Глобалізація, економіка, економічний розвиток, інформатизація, інформаційний простір, інформаційнокомунікаційні технології.

\section{ИНФОРМАТИЗАЦИЯ ГЛОБАЛЬНОГО ЭКОНОМИЧЕСКОГО РАЗВИТИЯ И МЕСТО УКРАИНЫ В ИНФОРМАЦИОННОМ ПРОСТРАНСТВЕ}

Казакова Надежда Артуровна, канд. географ. наук, профессор, Харьковский национальный университет имени В. Н. Каразина, пл. Свободы, 6, г. Харьков, Украина, 61022, e-mail: meo_1@ukr.net, ORCID: https://orcid.org/0000-00022455-7503

Давыденко Инна Владимировна, канд. филолог. наук, Харьковский национальный университет имени В. Н. Каразина, пл. Свободы, 6, г. Харьков, Украина, 61022, e-mail: i.v.davydenko@karazin.ua, ORCID: https://orcid.org/0000-0001-6379-343X Штыколенко Алла Николаевна, студент, Харьковский национальный университет имени В. Н. Каразина, пл. Свободы, 6, г. Харьков, Украина, 61022, e-mail:: allaalla9955@gmail.com, ORCID: https://orcid.org/0000-0003-1628-6421

В данной публикации исследуется влияние информационно-коммуникационных технологий на мировую экономику; используя основные Индексы (Индекс сетевой готовности, Глобальный индекс инноваций, Индекс развития электронного правительства, Индекс электронного участия и Индекс развития ИКТ) авторы анализируют данные по развитию информационного общества. Информационно-коммуникационные технологии представляют собой неотъемлемую часть мировой экономики, ведь решающим фактором экономического развития страны выступает степень использования ИКТ в различных областях общественной жизни. Очевидным становится факт перехода от «старого индустриального порядка» к «новой экономике», которая затрагивает процессы производства, обработки и передачи информации, трансформируя экономику, политику и культуру в современном мире.

Стремительное развитие и распространение новых ИКТ технологий приобретает характер глобальной информационной революции. Это ведет к необратимой трансформации в новый постиндустриальный тип общества. Тема данного исследования является актуальной в научном и в практическом плане. Предметом исследования в статье является информатизация глобального экономического развития. Цель - исследование информатизационных процессов и анализ ИКТ как ресурса 
современного развития мировой экономики. Задача: изучение динамики развития информатизационных процессов и детальный анализ влияния ИКТ на глобальное экономическое развитие. Используются общенаучные методы: системный анализ, факторный анализ, графический метод. Результаты данного исследования: выявлены новые секторы структуры экономики и проанализировано позиционирование стран на мировом рынке. Авторы делают вывод, что благодаря развитию ИКТ интенсивно растут практически все сферы экономики, которые влияют на развитие государств и благосостояние людей.

Ключевые слова: Глобализация, информатизация, информационное пространство, информационно-коммуникационные технологии, экономика, экономическое развитие.

\section{References}

1. Khokhlova, Yu. Ye. (Red.). (2009). Glossariy po informatsionnomu obshchestvu. M.: Institut razvitiya informatsionnogo obshchestva. [in Russian]

2. Dyatlov, S. A., Maryanenko, V. P., \& Selishcheva, T. A. (2008). Informatsionno-setevaya ekonomika: struktura, dinamika, regulirovanie. SPb.: Asterion. [in Russian]

3. Matjushenko, I. Ju., Berenda, S. V., \& Rjeznikov, V. V. (2015). Jevrointeghracija Ukrajiny v systemi mizhnarodnoji ekonomichnoji integhraciji: navch. posibn. Kh.: KhNU im. V. N. Karazina. [in Ukrainian]

4. Golikov, A. P. (Red.). (2003). Mirovoe khozyaystvo i mezhdunarodnye ekonomicheskie otnosheniya: uchebnoe posobie. Simferopol: SONAT. [in Russian]

5. Knoema. (n.d.). Mirovoy Atlas Dannykh. Vzyato s https://knoema.ru/atlas [in Russian]

6. Kyzym, M. O., Matjushenko, I. Ju., \& Shostak, I. V. (2012). Perspektyvy rozvytku informacijnokomunikacijnykh tekhnologhij i shtuchnogho intelektu v ekonomikakh krajin svitu ta Ukrajiny. Kh.: VD «Inzhek». [in Ukrainian]

7. Sidenko, V. R. (2008). Globalizatsiya i ekonomicheskoe razvitie. T. 1. K.: Feniks. [in Russian]

8. AnnualReports.com. (n.d.). Annual Report and Form 10K 2017 . Retrieved from http://www.annualreports.com/Company/wyndham-worldwide-corporation

9. Sidorov, V.I., Babenko, V.A. , Perepelitsia, A.S. (2016). Clusterization the Countries by the Level Information in the Conditions of International Globalization. International Scientific Conference The Development of International Competitiveness: State, Region, Enterprise: Conference Proceeding, Part 1, December 16, 2016. Lisbon, Portugal: Baltija Publishing, pp. 11-15.

10. IHG. (n.d.). Annual Report and Form 20-F 2017. Retrieved from https://www.ihgplc.com/investors/annualreport? tab $=$ right

11. Soumitra, Dutta, Bruno, Lanvin, \& Sacha, Wunsch-Vincent. (Eds.). (2018). Global Innovation Index 2018 Report (11th ed.). Retrieved from https://www.globalinnovationindex.org/gii-2018-report

12. Babenko, V., Perepelytsia, A. (2018). Research of the informatization process development of the countries of the world. Technology audit and production reserves, Vol. 6, No 5(44), pp. 22-29. DOI: https://doi.org/10.15587/23128372.2018.146333

13. Babenko, V., Perevozova, I., Mandych, O., Kvyatko, T., Maliy, O., Mykolenko, I., (2019). World informatization in conditions of international globalization: Factors of influence. Global Journal of Environmental Science and Management, 5 (Special issue), pp. 172-179. DOI: 10.22034/gjesm.2019.05.SI.19

14. Marriott International, Inc. (n.d.). 2017 Annual Report. Retrieved from https://marriott.gcs-web.com/staticfiles/b82978a6-9d28-4e38-9855-fc4ae2cebe11

15. International Telecommunication Union. (n.d.). Measuring the Information Society Report 2017. Retrieved from https://www.itu.int/en/ITU-D/Statistics/Pages/publications/mis2017.aspx

16. World Economic Forum. (2016). Networked Readiness Index. Retrieved from http://reports.weforum.org/global-information-technology-report-2016

UN E-Government Knowledgebase. (n.d.). UN E-Government Survey 2018. Retrieved from https://publicadministration.un.org/egovkb/en-us/Reports/UN-E-Government-Survey-2018

17. UN E-Government Knowledgebase. (n.d.). UN E-Government Survey 2018 . Retrieved from https://publicadministration.un.org/egovkb/en-us/Reports/UN-E-Government-Survey-2018 